\title{
$\cdot \nabla$ \\ IJCRR \\ Correlation between Vitamin D, Some Circulating Micro RNA with CRP and Faecal Calprotectin in Patients with Crohn's Disease
}

Section: Healthcare

ISI Impact Factor

(2019-20): 1.628

IC Value (2019): 90.81

$\operatorname{SJIF}(2020)=7.893$

(c) (i) (3)

Copyright@IJCRR

\author{
Antonia Atanassova ${ }^{1,3}$, Avgustina Georgieva ${ }^{1,2}$, Trifon Chervenkov ${ }^{4}$
}

\begin{abstract}
'Gastroenterology Clinic, "St. Marina "University Hospital - Varna, Bulgaria; ${ }^{2}$ Second lnternal Medicine Department, Medical University Varna, Bulgaria; ${ }^{3}$ Department of Anatomy and Cell Biology, Medical University - Varna, Bulgaria; ‘Department of Medical Genetics, Medical University - Varna, Bulgaria.
\end{abstract}

\section{ABSTRACT}

Introduction: The mal-absorption and the inflammation participate in the pathogenesis of Crohn's disease (CD) and influence the vitamin D levels. Serum microRNAs (miRNAs) are secreted during the inflammation in the gastrointestinal tract and therefore could affect the regulatory functions of vitamin $D$ and its signal pathways via negative feedback.

Objective: This study aims to assess the relationship between the Vitamin D serum levels and the expression of several circulating miRNAs in patients with CD and to correlate their levels with the activity of the disease.

Methods: 15 miRNAs expression was assessed using reverse transcriptase quantitive real-time PCR in 27 consecutive CD patients and then correlated with the serum level of $25(\mathrm{OH}) \mathrm{D}$, C-reactive protein $(\mathrm{CRP})$, faecal calprotectin (FCP) and clinical Crohn's disease assessment index (CDAI).

Results: Activity of $C D$ is a risk factor for a decrease in the $25(\mathrm{OH}) \mathrm{D}$ serum levels $(\mathrm{OR}=7.5(1,09-51,52 ; \mathrm{p}<0.05)$. There is a strong inverse correlation between the levels of FCP and $25(\mathrm{OH}) \mathrm{D}(\mathrm{r}=-0.641 ; \mathrm{p}<0.001)$. The results indicate that $25(\mathrm{OH}) \mathrm{D}$ deficiency induces the highest risk for a change in the miRNA-96_1 serum expression.

Conclusion: The 25(OH)D serum levels and serum expression of miRNA-96_1, miRNA-142-5p_1, miRNA-191_1 and miRNA199a_1 open an opportunity for optimization of the initial assessment of CD and potential as a prognostic tool.

Key Words: Crohn's disease, Micro-RNA, Vitamin D, CRP, Fecal calprotectin

\section{INTRODUCTION}

Crohn's disease $(\mathrm{CD})$ is a chronic recurrent disease, involving different segments of the gastrointestinal tract. Its pathogenesis is characterized by multilayer interaction between genetic predisposition, environmental factors, gut microbiome and imbalanced immune homeostasis, leading to intestinal inflammation., ${ }^{2,3}$ The precise molecular pathophysiology, leading to the development of $\mathrm{CD}$, is still obsolete. The activity of the disease is currently measured with different clinical indexes and the most widely used is the Crohns's Disease Activity Index (CDAI). ${ }^{4}$

The serum C-reactive protein (CRP) and the faecal calprotectin $(\mathrm{FCP})$ are widely used serum biomarkers in $\mathrm{CD}$. Unfortunately, their specificity and sensitivity are not high. This indicates the need for other biomarkers, that on one side would correlate with the molecular mechanisms during the early development of the disease and on the other - with the disease progression, the development of complications and would be valuable in the prediction of treatment response.

Vitamin D (25-hydroxyvitamin D; [25 (OH) D]) is an immune modulator of the innate and the acquired immune response. Levels of 25(OH)D in patients with CD correlate the activity of their disease ${ }^{5}$ : low levels $(<30 \mathrm{mg} / \mathrm{ml})$ are a risk factor for loss or no response to anti-TNF treatment (HR = 3, 49, 95\% CI: 1, 34-9,09). ${ }^{6} 25(\mathrm{OH}) \mathrm{D}$ deficiency in patients with inflammatory bowel disease (IBD) is also reported to increase the risk of disease relapse, frequent hospitalizations and disease-related surgeries. ${ }^{7}$ The activity of CD correlates with the 25(OH)D levels, but until the present, it is not clear whether a decrease in $25(\mathrm{OH}) \mathrm{D}$ levels is a primary triggering the disease relapse event or a secondary consequence of the activated disease. These define the levels of $25(\mathrm{OH}) \mathrm{D}$ as a new non-invasive biomarker, that is related to the pathogenesis of the disease. It also reflects the changes in the im-

\section{Corresponding Author:}

Avgustina Chavdarova Georgieva. MD, PhD, Assistant Professor, Clinic of Gastroenterology, Multi Profile University Hospital for Active Treatment "Sveta Marina", City of Varna, Bulgaria; E-mail: avgustina_dobreva@yahoo.com

ISSN: 2231-2196 (Print)

ISSN: 0975-5241 (Online)

Received: 23.09 .2020

Revised: 13.11 .2020

Accepted: 03.01 .2021

Published: 04.06 .2021 
mune system and the effect of the treatment of the disease. The activity of the disease could be bridged to the pathogenetic mechanisms that are specific to the IBD as it influences the micro-RNA (miRNA) expression of all immune cells. ${ }^{8}$ Patients with $\mathrm{CD}$ frequently have $25(\mathrm{OH}) \mathrm{D}$ deficiency and the levels of $25(\mathrm{OH}) \mathrm{D}$ are significantly lower as compared to healthy controls. ${ }^{9}$

miRNAs are small non-coding RNA molecules with a length of 18-23 nucleotides. They participate in many cell processes as cell differentiation, growth, apoptosis and autophagy as well as in proliferation. miRNAs function as regulators of the protein synthesis via induction of the degradation of the mRNA or silencing the translation..$^{10}$ The circulating miRNAs can be found in a stable form in many-body liquids, incl. in the serum. ${ }^{11}$ Recent research reports that the miRNA expression profiles in blood of patients with $\mathrm{CD}$ may be different. ${ }^{12,13}$

Serum miRNAs are secreted in the process of inflammation of the gastrointestinal tract and they mediate the $25(\mathrm{OH})$ D signalling capacity via feedback control. ${ }^{8,12,14}$ Paraskevi et al. identified that the expression of 11 serum miRNAs is increased in patients with CD (MiR-16, miR-23a, miR29a, miR-106a, miR-107, miR-126, miR-191, miR-199a-5p, miR-200c, miR-362-3p, miR-532-3p) 12. Other publications assessed the serum expression of 11 miRNAs in children with CD (MiR-16, miR-484, miR-30e, miR-106a, miR-195, miR-20a, miR-21, miR-140, let-7b, miR-192, miR-93), and report high specificity and sensitivity. ${ }^{14}$

In the present study we aimed to assess the relationship between the 25(OH)D serum levels and the expression of several circulating miRNAs in patients with $\mathrm{CD}$ and to try to correlate their levels with the clinical or biochemical activity of the disease.

\section{MATERIALS AND METHODS}

The study was initiated after approval and permission №82 / 28.03.2019 of the Ethics Commission for scientific research at the Medical University - Varna, Bulgaria. Before study entry, all patients signed an Informed consent form. Vitamin $\mathrm{D}$ was measured in 27 consecutive patients with $\mathrm{CD}$, who attended the Gastroenterology Clinic during a period of one year ( from April 2019 to April 2020). 25(OH)D serum concentrations were measured by a commercial paramagnetic particle chemiluminescent immunoassay for the quantitative determination of the total 25-hydroxyvitamin D $[25(\mathrm{OH})$ vitamin D] levels use on Access 2 Immunoassay Systems. $25(\mathrm{OH}) \mathrm{D}$ deficiency is defined as a serum level of $25 \mathrm{OHD}$ lower than $50 \mathrm{nmol} / \mathrm{L}$. Serum level above $50 \mathrm{nmol} / \mathrm{L}$ but lower than $75 \mathrm{nmol} / \mathrm{L}$ are classified as $25(\mathrm{OH}) \mathrm{D}$ insufficiency.
All patients were classified according to the Montreal classification. The clinical course, treatment regimens and the occurrence of extraintestinal manifestations (EIMs) were recorded.

Disease activity was evaluated by clinical symptoms, biochemical inflammatory parameters (CRP, FCP) and validated clinical indices (CDAI). In the evaluation of FCP, the criteria used were normal, $<50 \mathrm{mg} / \mathrm{g}$ and for CRP were considered as reagents for values $>5 \mathrm{mg} / 1$.

Levels of miRNAs were assessed in blood serum. $5 \mathrm{ml}$ of blood was obtained via peripheral venous puncture with closed system BD Vacutainer ${ }^{\mathrm{TM}}$ SST ${ }^{\mathrm{TM}}$ II Advance (Becton Dickinson, USA). After withdrawal, the blood sample was held for 30 minutes at room temperature for clothing. Subsequently, it was centrifuged at $500 \times \mathrm{g}$ for 15 minutes at room temperature and the serum was separated and divided into aliquots of $500 \mu \mathrm{l}$ that were immediately stored at $-80^{\circ} \mathrm{C}$ until the moment of the analysis.

miRNAs were isolated from $200 \mu 1$ serum using a pre-existing commercial miRNeasy Serum/Plasma Kit (50), catalogue №217184 (QIAGEN, Germany) as per the protocol of the manufacturer. $3,5 \mu \mathrm{l}(1,6 \times 108$ копия на $\mu \mathrm{l})$ control miRNA C. Elegans miR-39: miRNeasy Serum/Plasma Spike-In Control, catalogue №219610 (QIAGEN, Germany), was added to each sample for normalization control; the samples were afterwards eluted in $14 \mu 1$ RNA-ase free water.

Each of the samples was subsequently submitted to reverse transcription via ready-to-use commercial kit miScript II RT Kit (50), catalogue №218161 (QIAGEN, Germany) as per manufacturer's protocol from 2,5 $\mu 1$ eluted miRNA in a final volume of $10 \mu 1$ with HiFlex buffer and it was incubated at $37^{\circ} \mathrm{C}$ for 60 minutes and the enzyme was inactivated at 95 ${ }^{\circ} \mathrm{C}$ for 5 minutes.

Each of the samples was then submitted to quantitative real time polymerase chain reaction (rt-PCR) via a ready-touse commercial kit miScript SYBR Green PCR Kit (200), catalogue № 218073 (QIAGEN, Germany) and prepared primers miScript Primer Assay (100), catalogue № 218300 (QIAGEN, Germany) as per manufacturer's protocol: $1 \mu \mathrm{l}$ complementary DNA (cDNA) in $10 \mu 1$ reactions in 3-times repetitions for 15 target miRNA in 384 well plates. The used miScript Primer Assay primers(100), catalogue № 218300 (QIAGEN, Germany) are as follows (the reference number is in the brackets): Hs miR-28 1 (MS00003255), Hs miR29c_1 (MS00003269), Hs_miR-96_1 (MS00003360), Hs miR-191_1 (MS00003682), Hs_miR-451_1 (MS00004242), Hs_miR-142-5p_1 (MS00006671), Hs_miR-199a_1 (MS00006741), Hs_miR-363_1 (MS00009576), Ce_miR39_1 (MS00019789), Hs_miR-144_4 (MS00020328), Hs_miR-142-3p_2 (MS00031451), Hs_miR-155_2 (MS00031486), Hs_miR-16_2 (MS00031493), Hs_RNU6- 
2_11 (MS00033740), Hs_miR-1228-3p_1 (MS00042385). The used temperature parameters are as follows: maintenance for 15 minutes at $95{ }^{\circ} \mathrm{C}$ for enzyme activation; $40 \mathrm{cy}$ cles of 15 seconds at $94{ }^{\circ} \mathrm{C} ; 30$ seconds at $70{ }^{\circ} \mathrm{C}$ with fluorescent reading; analysis of the melting curve in order to prove the specificity of the amplification: primary denaturation for 15 seconds at $95^{\circ} \mathrm{C}$ and cooling to $55^{\circ} \mathrm{C}$ for 60 seconds with an increase to $95{ }^{\circ} \mathrm{C}$ with velocity of $+0,05{ }^{\circ} \mathrm{C}$ per second and fluorescent reading. The analysis was done by QuantStudio Dx instrument of Applied Biosystems (USA) company; a threshold cycle $(\mathrm{Ct})$ was assessed for each sample.

Receiver Operating Characteristic Curve (ROC) was made to detect the diagnostic performance of the test, sensitivity, specificity, positive and negative predictive values. The significance of the obtained results was judged at the $5 \%$ level.

\section{Analyses}

Serum levels of 25(OH)D were measured and correlated with serum CRP, FCP, CDAI and the expression of different miRNAs. Additional co-variation models, including stratification factors as age, the sex were assessed. Correlation of levels of miRNAs with some clinical factors as $25(\mathrm{OH}) \mathrm{D}$ deficiency, treatment with corticosteroids or anti-TNF antibodies was also done. The Spearman correlation coefficient was used for analyzing the correlation between the serum concentration of $25(\mathrm{OH}) \mathrm{D}$ and the serum expression of some microRNAs.

The results were calculated with SPSS, v. 20.0 for Windows. We used variation, correlation, regression analyses as well risk assessment and comparative analyses ( $\chi^{2}, \mathrm{t}$-test), $\mathrm{p}<0.05$ was used as a level of significance.

\section{RESULTS}

Table 1 shows a summary of the characteristics of the patients with Crohn's disease. The mean 25(OH)D expression levels in patients with $\mathrm{CD}$ is $42.97 \mathrm{nmol} / \mathrm{L} \pm 16.75 \mathrm{nmol} / \mathrm{L}$, with variations from $2,76 \mathrm{nmol} / \mathrm{L}$ to $73,17 \mathrm{nmol} / \mathrm{L}$. There is no correlation between the $25(\mathrm{OH}) \mathrm{D}$ serum levels and the sex or age of the patients. The $25(\mathrm{OH}) \mathrm{D}$ serum expression levels differ significantly $(\mathrm{p}=0.043)$ between patients with activity $(39.45 \mathrm{nmol} / \mathrm{L} \pm 16.65 \mathrm{nmol} / \mathrm{L})$ vs patients in remission $(53.02 \mathrm{nmol} / \mathrm{L} \pm 16.76 \mathrm{nmol} / \mathrm{L})$. The activity of the $\mathrm{CD}$ is a risk factor for a decrease in the $25(\mathrm{OH}) \mathrm{D}$ serum levels $(\mathrm{OR}=7.5(1,09-51,52 ; \mathrm{p}<0.05)$. The relative rate of patients with $\mathrm{CD}$ and $25(\mathrm{OH}) \mathrm{D}$ serum levels below $50 \mathrm{nmol} / \mathrm{L}$ is 63.0 $\%$. There is an inverse relationship between $25(\mathrm{OH}) \mathrm{D}$ and the activity of the disease, measured by CDAI ( $\mathrm{r}=-0.421$; $\mathrm{p}=0.029$ ) (Figure 1), showing that $25(\mathrm{OH}) \mathrm{D}$ serum levels decrease with the increase of CDAI.

The most widely clinically used parameters as CRP and faecal calprotectin (FCP) were correlated with the levels of
$25(\mathrm{OH}) \mathrm{D}$. There is an inverse correlation, showing that the $25(\mathrm{OH}) \mathrm{D}$ serum levels decrease in patients with increased levels of CRP and FCP. There is a weak inverse correlation between $\mathrm{CRP}$ and 25(OH)D $(\mathrm{r}=-0.202 ; \mathrm{p}<0.05)$ (Figure 2).

The FCP is a widely used biomarker, used to monitor patients with $\mathrm{CD}$. We found a strong inverse correlation between the levels of FCP and the 25(OH)D serum levels ( $\mathrm{r}=-$ $0.641 ; \mathrm{p}<0.001$ ) (Figure 3).

The expression of some microRNAs and their correlation with the levels of $25(\mathrm{OH}) \mathrm{D}$ is presented in Table 2. The expression of the different miRNAs is different as compared to the serum levels of $25(\mathrm{OH}) \mathrm{D}$. The expression of two miRNAs - miRNA-28_1 and miRNA-1228-3p_1, is increased in patients with normal $25(\mathrm{OH}) \mathrm{D}$ serum levels. The expression of all other miRNAs is increased in $25(\mathrm{OH}) \mathrm{D}$ deficiency.

Table 3 shows the risk analysis of the expression of miRNAs and the 25(OH)D levels. The results indicate that 25(OH)D deficiency induces the highest risk for a change in the miRNA-96_1 serum expression.

There is no correlation between $25(\mathrm{OH}) \mathrm{D}$ expression and the tested miRNAs in patients with CD and intestinal complications. There is an increased expression of all tested miRNAs in patients with either $25(\mathrm{OH}) \mathrm{D}$ deficiency, treatment with corticosteroids or anti-TNFantibodies.

\section{DISCUSSION}

Our results confirm some previously reported data that there is a high prevalence of $25(\mathrm{OH}) \mathrm{D}$ deficiency among patients with $\mathrm{CD}$. In Ireland, $63 \%$ of the patients with $\mathrm{CD}$ have levels of $25(\mathrm{OH}) \mathrm{D}<50 \mathrm{nmol} / \mathrm{L} .{ }^{15} \mathrm{The} 25(\mathrm{OH}) \mathrm{D}$ deficiency rates in Canada are $22 \%(<40 \mathrm{nmol} / \mathrm{L}) .{ }^{16}$ A Japanese trial reported that $27,3 \%$ of the patients with $\mathrm{CD}$ are $25(\mathrm{OH}) \mathrm{D}$ deficient $(<25 \mathrm{nmol} / \mathrm{L}){ }^{17}$

There is already data that significantly lower $25(\mathrm{OH}) \mathrm{D}$ levels are frequently seen among patients with IBD; it is also reported that lower levels correlate with the activity of the disease. Our results and the correlation analysis of $25(\mathrm{OH})$ D serum levels and activity of CD confirm previously reported data by Cheong-Lee $\mathrm{C}$ et. al. and Chatu et al. in IBD patients, the levels of CRP inversely correlate with the levels of $25(\mathrm{OH}) \mathrm{D} .{ }^{18,19}$ Chat et al. do not find differences between the mean 25(OH)D levels in patients with $\mathrm{CD}$ or ulcerative colitis. Despite this, the mean 25(OH)D levels in Asian and Afro-American people are significantly lower in comparison with Caucasians. ${ }^{19}$

It was proved that the levels of $25(\mathrm{OH}) \mathrm{D}$ inversely correlate with the disease activity, assessed as per CDAI. ${ }^{20}$ Joseph et al. show that patients with $\mathrm{CD}$ have significantly lower $25(\mathrm{OH}) \mathrm{D}$ levels as compared to healthy controls. ${ }^{21}$ Refer- 
ringtodiseaseactivity, some authors report that patients with mild $\mathrm{CD}$ have $25(\mathrm{OH}) \mathrm{D}$ levels, comparable to healthy controls. In moderately severe disease, the $25(\mathrm{OH}) \mathrm{D}$ levels are significantly lower. ${ }^{21}$ Additionally, Suibhneet al. report that $25(\mathrm{OH}) \mathrm{D}$ deficiency is a frequent event in patients with $\mathrm{CD}$ even in clinical remission..$^{15}$ The localization of the disease or its activity, together with the presence or not of the previous resection might not be the only factors, influencing the bioavailability of $25(\mathrm{OH}) \mathrm{D} .^{22}$

The number of publications, assessing the potential relation between 25(OH)D levels and bowel inflammation, using FC Pisscarce. ${ }^{23}$ In Australia, Garg et al. study 40 patients with Crohn's disease and conclude that there is a strong inverse correlation between 25(OH)D and FCP levels. ${ }^{23}$ These results are also confirmed in our study.

The levels of the differently expressed miRNAs serum profiles as IBD diagnostic and monitoring biomarkers is largely studied. Data about different miRNAs expression and serum 25(OH)D levels in immune-mediated diseases is scarce. A. Hsieh published in 2016 that there is a correlation between miRNA-142-3p and 25(OH)D in mice models. ${ }^{24}$ The author concludes that the $25(\mathrm{OH}) \mathrm{D}$ deficiency changes the miRNA-142-3p -miRNA, targeted to the ATG16L1 autophagy gene, contributes to the increased sensitivity in IBD. ${ }^{24}$ While assessing the $25(\mathrm{OH}) \mathrm{D}$ and some miRNAs levels in patients with rheumatoid arthritis, another author reports the inverse correlation between the two biomarkers. ${ }^{25}$ Despite the design, methods and population heterogeneity (in mice or men) in the cited publications, an inverse correlation between 25(OH)D and the tested miRNAs levels are consistently noted. Our results also confirm that in most miRNAs (miRNA-96_1, miRNA-142-5p_1, miRNA-191_1 and miRNA-199a_1) the correlation is inverse and only in two of the tested miRNAs (miRNA-28_1 and miRNA-1228-3p_1), it is proportional.

Our study reports the first results of correlation between 25(OH)D and some miRNAs levels in patients with $\mathrm{CD}$ in Bulgaria. Worldwide, the number of similar scientific data in patients with $\mathrm{CD}$ is also very scarce, limiting the possibility to compare our results or test their validity with others. Larger prospective trials in patients with $\mathrm{CD}$ are needed to prove definitively the validity of the reported results.

\section{CONCLUSION}

The 25(OH)D serum levels inversely correlate with the levels of the serum biomarkers CRP and FCP, as well as with the $\mathrm{CD}$ activity index CDAI, used to measure the activity of CD. On the other hand, the low 25(OH)D serum levels correlate with increased serum expression of miRNA-96_1, miRNA142-5p_1, miRNA-191_1 and miRNA-199a_1. These data open an opportunity for optimization of the initial assess- ment of CD and potential for prediction of the activity of the disease if these biomarkers are combined as a prognostic tool.

Approval: Approval and permission №82 / 28.03.2019 of the Ethics Commission for scientific research at the Medical University - Varna, Bulgaria.

\section{ACKNOWLEDGEMENT}

Authors acknowledge the immense help received from the scholars whose articles are cited and included in references of this manuscript. The authors are also grateful to authors/ editors/publishers of all those articles, journals and books from where the literature for this article has been reviewed and discussed.

\section{Source of funding: None}

Conflicts of interest: None to declare.

\section{REFERENCES}

1. Baumgart DC, Sandborn WJ. Crohn's disease. Lancet. 2012;380:1590-1605.

2. Loddo I, Romano C. Inflammatory Bowel Disease: Genetics, Epigenetics, and Pathogenesis. Front Immunol. 2015;2(6):551.

3. Kaser A, Zeissig S, Blumberg RS. Inflammatory bowel disease. Annu Rev Immunol. 2010;28:573-621.

4. Sands BE. Biomarkers of Inflammation in Inflammatory Bowel Disease. Gastroenterology. 2015;149(5):1275-1285.

5. Nielsen OH, Rejnmark L, Moss AC. Role of Vitamin D in the Natural History of Inflammatory Bowel Disease. J Crohns Colitis. 2018;25;12(6):742-752.

6. Zhao H, Pullagura SRN, Rieger S, Lisse TS. Chapter 15 - Vitamin D and MicroRNAs. Vitamin D (Fourth Edition). Volume 1: Biochemistry, Physiology and Diagnostics, 2018; 245-267.

7. Caviezel D, Maissen S, Niess J, H, Kiss C, Hruz P. High Prevalence of Vitamin D Deficiency among Patients with Inflammatory Bowel Disease. Inflamm Intest Dis 2017;2:200-210.

8. Lin S, Wang Y, Li L, Chen P, Mao R, Feng R, et al. A New Model Based on 25-Hydroxyvitamin D3 for Predicting Active Crohn's Disease in Chinese Patients. Mediators Inflamm. 2018;16;2018:3275025.

9. Zator ZA, Cantu SM, Konijeti GG, Nguyen DD, Sauk J, Yajnik $\mathrm{V}$, et al. Pretreatment 25-hydroxyvitamin D levels and durability of anti-tumor necrosis factor- $\alpha$ therapy in inflammatory bowel diseases. J Parenter Enteral Nutr. 2014;38(3):385-91.

10. Kalla R, Ventham NT, Kennedy NA, Quintana JF, Nimmo ER, Buck AH, Satsangi J. MicroRNAs: new players in IBD. Gut. 2015;64(3):504-17.

11. Manier S, Liu CJ, Avet-Loiseau H, Park J, Shi J, Campigotto F, et al. Prognostic role of circulating exosomal miRNAs in multiple myeloma. Blood. 2017;27;129(17):2429-2436.

12. Paraskevi A, Theodoropoulos G, Papaconstantinou I, Mantzaris G, Nikiteas N, Gazouli M. Circulating MicroRNA in inflammatory bowel disease. J Crohns Colitis. 2012;6(9):900-4.

13. Iborra M, Bernuzzi F, Correale C, Vetrano S, Fiorino G, Beltrán $\mathrm{B}$, et al. Identification of serum and tissue micro-RNA expression profiles in different stages of inflammatory bowel disease. Clin Exp Immunol. 2013;173(2):250-8. 
14. Zahm AM, Thayu M, Hand NJ, Horner A, Leonard MB, Friedman JR. Circulating microRNA is a biomarker of pediatric Crohn disease. J Pediatr Gastroenterol Nutr. 2011;53(1):26-33.

15. Suibhne TN, Cox G, Healy M, O’Morain C, O'Sullivan M. Vitamin D deficiency in Crohn's disease: prevalence, risk factors and supplement use in an outpatient setting. J Crohns Colitis. 2012;6(2):182-8.

16. Siffledeen JS, Siminoski K, Steinhart H, Greenberg G, Fedorak $\mathrm{RN}$. The frequency of vitamin $\mathrm{D}$ deficiency in adults with Crohn's disease. Can J Gastroenterol. 2003;17(8):473-8.

17. Tajika M, Matsuura A, Nakamura T, Suzuki T, Sawaki A, Kato $\mathrm{T}$, et al. Risk factors for vitamin D deficiency in patients with Crohn's disease. J Gastroenterol. 2004;39(6):527-33.

18. Fu YT, Chatur N, Cheong-Lee C, Salh B. Hypovitaminosis D in adults with inflammatory bowel disease: potential role of ethnicity. Dig Dis Sci. 2012;57(8):2144-8.

19. Chatu S, Chhaya V, Holmes R, Neild P, Kang JY, Pollok RC, et al. Factors associated with vitamin $\mathrm{D}$ deficiency in a multicultural inflammatory bowel disease cohort. Frontline Gastroenterol. 2013;4(1):51-56.
20. Jørgensen SP, Hvas CL, Agnholt J, Christensen LA, Heickendorff L, Dahlerup JF. Active Crohn's disease is associated with low vitamin D levels. J Crohns Colitis. 2013;7(10):e407-13.

21. Joseph AJ, George B, Pulimood AB, Seshadri MS, Chacko A. $25(\mathrm{OH})$ vitamin D level in Crohn's disease: association with sun exposure \& amp; disease activity. Indian J Med Res 2009;130:133-137.

22. Farraye FA, Nimitphong H, Stucchi A, Dendrinos K, Boulanger AB, Vijjeswarapu A, et al. Use of a novel vitamin D bioavailability test demonstrates that vitamin $\mathrm{D}$ absorption is decreased in patients with quiescent Crohn's disease. Inflamm Bowel Dis. 2011;17(10):2116-21.

23. Garg M, Rosella O, Lubel JS, Gibson PR. Association of circulating vitamin $\mathrm{D}$ concentrations with intestinal but not systemic inflammation in inflammatory bowel disease. Inflamm Bowel Dis. 2013;19(12):2634-43.

24. Hsieh A. Effect of Vitamin D Deficiency on Autophagy in the Intestine via MicroRNA Regulation. Master of Science. Institute of Medical Science University of Toronto, 2016.

25. Li D. Micrornas and immunomodulation by vitamin D. University of Birmingham, 2019.

Table 1: Characteristics of the patients with Crohn's disease according the Montreal classification

\begin{tabular}{|c|c|c|}
\hline \multicolumn{2}{|l|}{ Baseline characteristics } & \multirow{2}{*}{$\begin{array}{c}\text { Crohn's disease }(\mathbf{n}=27) \\
41.51 \pm 13.55(18-75)\end{array}$} \\
\hline Age, years & Current & \\
\hline (mean $\pm \mathrm{SD}$, range) & Onset of complaints & $33.97 \pm 13.45(11-75)$ \\
\hline & Age at diagnosis & $36.11 \pm 13.02(14-75)$ \\
\hline \multirow[t]{2}{*}{ Sex } & Male & $14 / 51.8 \%$ \\
\hline & Female & $13 / 48.2 \%$ \\
\hline \multirow[t]{3}{*}{ Location } & L1 & $17 / 62.9 \%$ \\
\hline & $\mathrm{L} 2$ & $3 / 11.1 \%$ \\
\hline & $\mathrm{L}_{3}$ & $7 / 26.0 \%$ \\
\hline \multirow[t]{4}{*}{ Behavior } & $\mathrm{B} 1$ & $11 / 40.7 \%$ \\
\hline & $\mathrm{B} 2$ & $9 / 33 \cdot 3 \%$ \\
\hline & B3 & $6 / 22.2 \%$ \\
\hline & $\mathrm{B}_{2}-\mathrm{B}_{3}$ & $1 / 3.8 \%$ \\
\hline Duration of IBD, months & (mean $\pm \mathrm{SD}$, range) & $66.91 \pm 59.67(3-204)$ \\
\hline \multirow[t]{4}{*}{ Treatment } & 5ASA & $2 / 7.4 \%$ \\
\hline & Corticosteroids & $7 / 25.9 \%$ \\
\hline & Immune modulators & $16 / 59 \cdot 3 \%$ \\
\hline & Biological treatment & $2 / 7.4 \%$ \\
\hline
\end{tabular}

Table 2: Expression of miRNA inpatients with Crohn's disease and correlation with the 25(OH)D serum levels

\begin{tabular}{|c|c|c|c|c|c|}
\hline miRNA & $\begin{array}{c}25(\mathrm{OH}) \mathrm{D} \\
<50 n \mathrm{~mol} / \mathrm{L}\end{array}$ & $\begin{aligned} & 25(\mathrm{OH}) \mathrm{D} \\
\geq & 50 \mathrm{nmol} / \mathrm{L}\end{aligned}$ & Pvalue & $\begin{array}{c}\text { Expression of } \\
\text { miRNA }\end{array}$ & $\begin{array}{c}\text { Expression of } \\
25(\mathrm{OH}) \mathrm{D}\end{array}$ \\
\hline miRNA -16_2 & $3.59 \pm 2.17$ & $3.31 \pm 2.24$ & 0.739 & - & - \\
\hline miRNA-28_1 & $2.52 \pm 1.88$ & $4.54 \pm 8.14$ & 0.05 & $\uparrow$ & $\uparrow$ \\
\hline miRNA -29c_1 & $2.08 \pm 1.04$ & $1.50 \pm 0.68$ & 0.139 & - & - \\
\hline miRNA-96_1 & $4.04 \pm 4.38$ & $0.82 \pm 0.65$ & 0.024 & $\uparrow$ & $\downarrow$ \\
\hline miRNA -142-5p_1 & $3.22 \pm 2.69$ & $1.84 \pm 0.85$ & 0.012 & $\uparrow$ & $\downarrow$ \\
\hline miRNA -142-3p_2 & $3.33 \pm 2.22$ & $2.71 \pm 1.69$ & 0.188 & - & - \\
\hline miRNA -144_4 & $2.54 \pm 1.32$ & $3.64 \pm 2.06$ & 0.345 & - & - \\
\hline
\end{tabular}


Table 2: (Continued)

\begin{tabular}{|c|c|c|c|c|c|}
\hline miRNA & $\begin{array}{c}25(\mathrm{OH}) \mathrm{D} \\
<50 n m o l / L\end{array}$ & $\begin{aligned} & 25(\mathrm{OH}) \mathrm{D} \\
\geq & 50 \mathrm{nmol} / \mathrm{L}\end{aligned}$ & Pvalue & $\begin{array}{l}\text { Expression of } \\
\text { miRNA }\end{array}$ & $\begin{array}{c}\text { Expression of } \\
25(\mathrm{OH}) \mathrm{D}\end{array}$ \\
\hline miRNA -155_2 & $3.14 \pm 2.69$ & $2.80 \pm 3.73$ & 0.687 & - & - \\
\hline miRNA -191_1 & $2.75 \pm 2.15$ & $1.97 \pm 0.88$ & 0.067 & $\uparrow$ & $\downarrow$ \\
\hline miRNA -199a_1 & $3.40 \pm 5.41$ & $1.77 \pm 0.99$ & 0.008 & $\uparrow$ & $\downarrow$ \\
\hline miRNA -363_1 & $2.48 \pm 1.72$ & $2.88 \pm 1.37$ & 0.958 & - & - \\
\hline miRNA -451_1 & $2.25 \pm 1.06$ & $2.96 \pm 2.36$ & 0.087 & - & - \\
\hline miRNA -1228-3p_1 & $1.68 \pm 1.74$ & $2.66 \pm 3.42$ & 0.05 & $\uparrow$ & $\uparrow$ \\
\hline
\end{tabular}

Table 3: Risk analysis of miRNAs expression in patients with Crohn's disease according to the $25(\mathrm{OH}) \mathrm{D}$ serum levels

\begin{tabular}{lccc} 
miRNAs & OR & $95 \%$ CI & P value \\
miRNA-28_1 & 2.77 & $0.264-29.047$ & 0.037 \\
miRNA-96_1 & 2.92 & $0.952-8.934$ & 0.049 \\
miRNA-142-5P_1 & 1.22 & $0.431-3.476$ & 0.052 \\
miRNA-191_1 & 1.67 & $0.257-10.792$ & 0.047 \\
miRNA-199a_1 & 2.77 & $0.264-29.047$ & 0.037 \\
miRNA-1228-3P_1 & 1.39 & $0.505-3.844$ & 0.053 \\
\hline
\end{tabular}

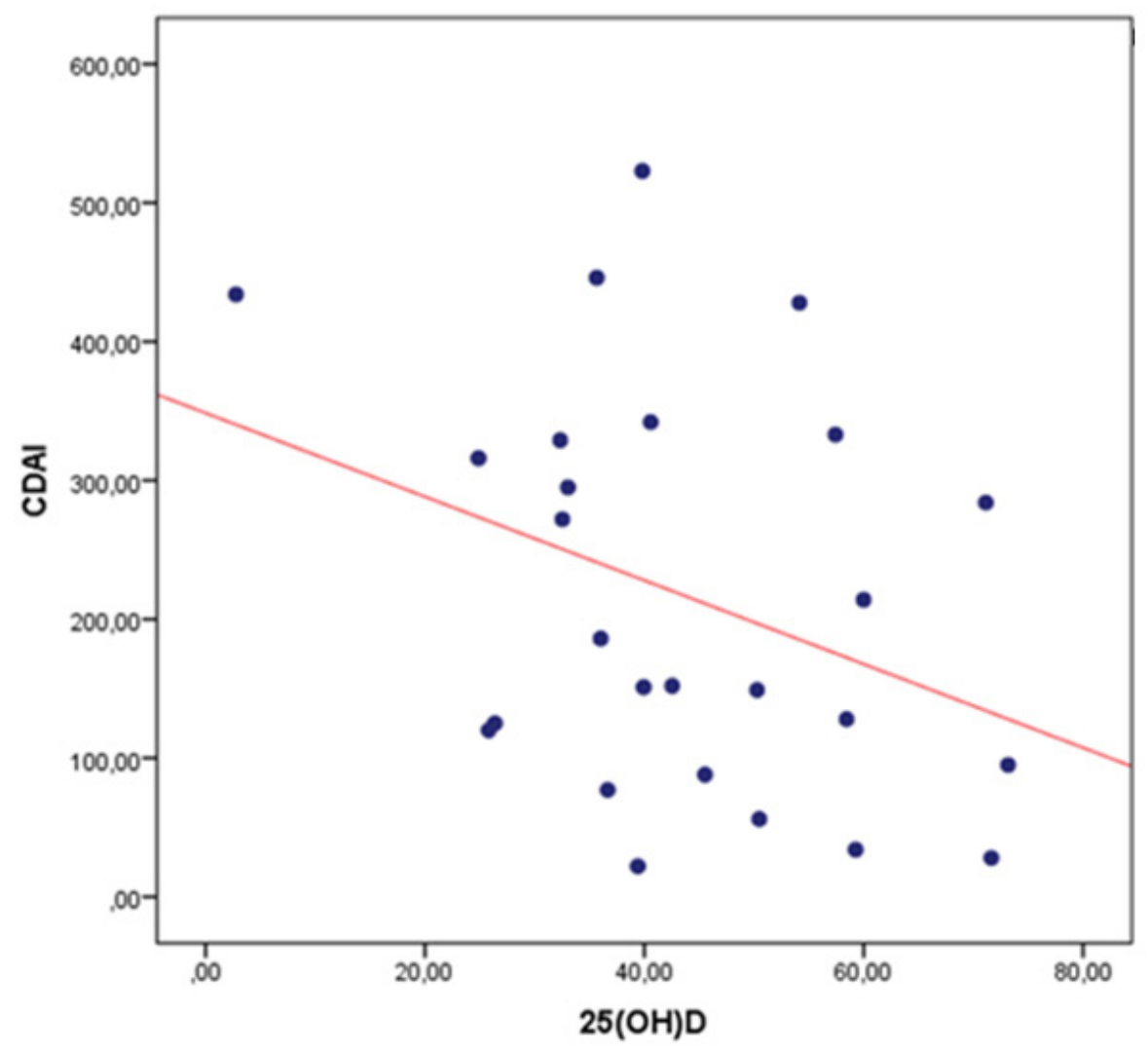

Figure 1: Correlation between CDAI and 25(OH)D levels. 


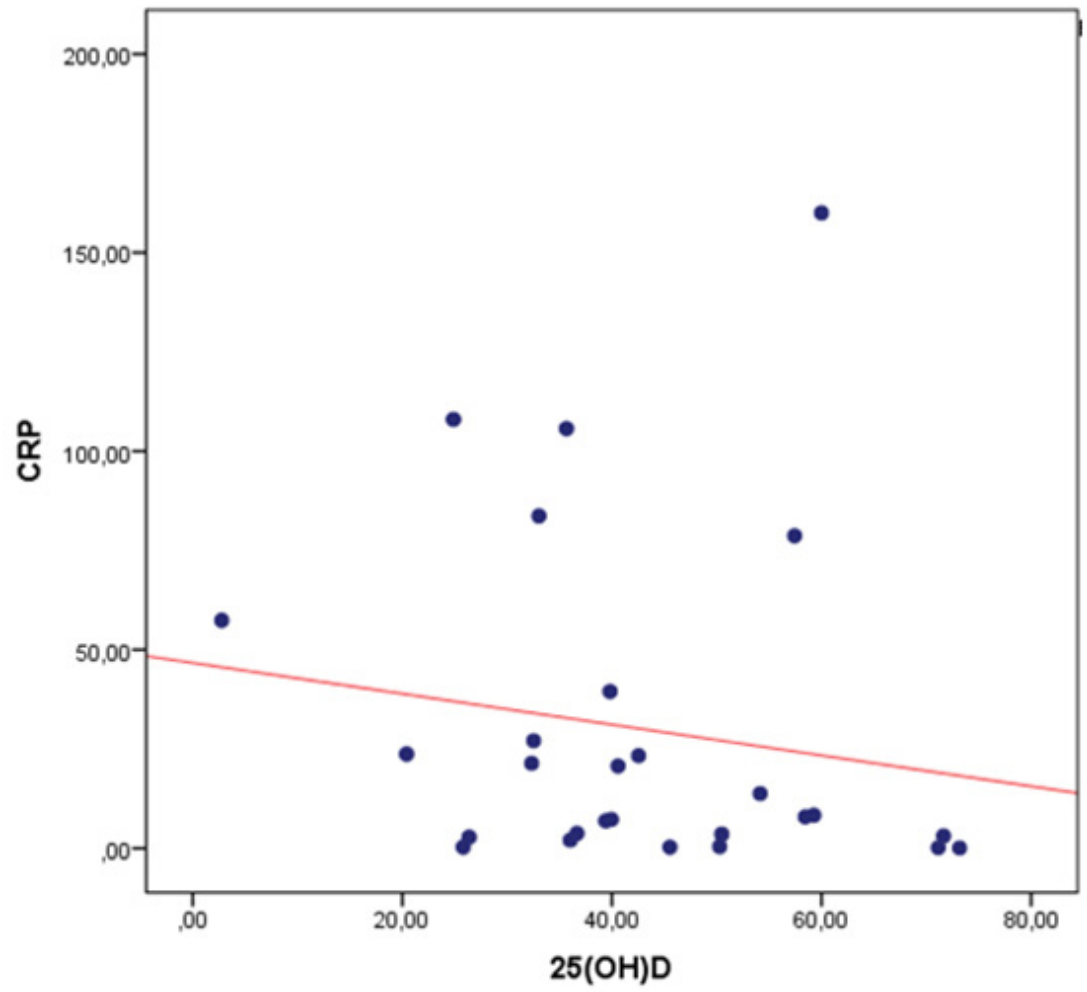

Figure 2: Correlation betweenCRPand 25(OH)D.

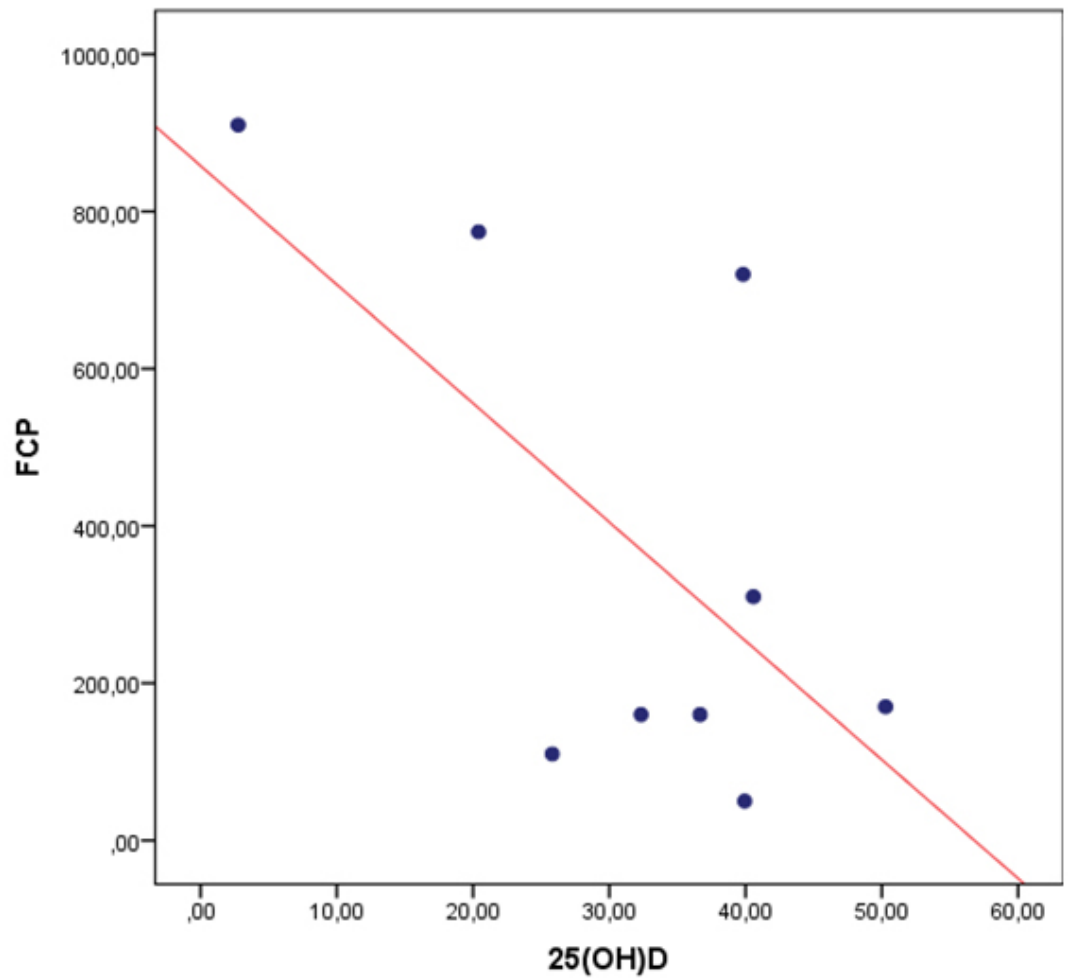

Figure 3: Correlation betweenFCPand 25(OH)D. 